\title{
The role of interleukin 22 in multiple sclerosis and its association with c-Maf and AHR
}

\author{
Michal Konrad Zarobkiewicz ${ }^{\mathrm{a}}$, Wioleta Kowalska ${ }^{\mathrm{a}}$, Miroslaw Slawinskib ${ }^{\mathrm{b}}$ Jacek Rolinski ${ }^{\mathrm{a}}$, Agnieszka Bojarska-Junak ${ }^{\mathrm{a}}$
}

The aim of this paper was to summarise knowledge of IL-22 involvement in multiple sclerosis (MS) and the possible link between IL-22 and two transcription factors - AHR and c-Maf. The conclusion is that despite numerous studies, the exact role of IL-22 in the pathogenesis of MS is still unknown. The expression and function of C-Maf in MS have not been studied. It seems that the functions of c-Maf and AHR are at least partly connected with IL-22, as both directly or indirectly influence the regulation of IL-22 expression. This possible connection has never been studied in MS.

Key words: multiple sclerosis, IL-22, transcription factors, c-Maf, AHR, EAE

Received: February 18, 2019; Revised: May 23, 2019; Accepted: May 24, 2019; Available online: June 4, 2019 https://doi.org/10.5507/bp.2019.024

(c) 2019 The Authors. This is an open access article licensed under the Creative Commons Attribution License (https://creativecommons.org/licenses/by/4.0/).

${ }^{a}$ Chair and Department of Clinical Immunology, Medical University of Lublin, Lublin, Poland

${ }^{b}$ Chair and Department of Histology and Embryology with Experimental Cytology Unit, Medical University of Lublin, Lublin, Poland Corresponding author:Michal Konrad Zarobkiewicz, e-mail:michal.zarobkiewicz@gmail.com

\section{INTRODUCTION}

IL-22 is one of the pro-inflammatory cytokines which are most probably important in the pathogenesis of numerous autoimmune diseases, including multiple sclerosis $^{1}$. IL-22- and Th22-oriented therapies provide optimism for a significant improvement in the treatment of a number of autoimmune diseases ${ }^{2}$. The current paper serves two main purposes. The first is to summarise the current state of research on IL-22 in MS. The second is to link the function of IL-22 and two transcription factors c-Maf and AHR.

\section{IL-22}

Interleukin 22 belongs to the interleukin 10 family along with IL-10, IL-19, IL-20, IL-24, IL-26 and IL-28A, IL-28B, IL-29 (ref. $\left.{ }^{3}\right)$. Initially, it was believed to be a Th1spectrum cytokine. Further investigations disproved this and identified Th17 and Th22 lymphocytes as its main source. Apart from these subpopulations, IL-22 is also produced by mast cells, CD11 $\mathrm{c}^{+}$dendritic cells, NK22 cells, $\gamma \delta$ T, NKT and LTi lymphocytes ${ }^{3}$. The role of IL-22 is two-fold - it has significant pro-inflammatory potential and it may also exhibit anti-inflammatory function ${ }^{3}$. The receptor for IL-22 has a heterodimeric structure; it is composed of IL-10R2 and IL-22R1 (ref. ${ }^{4}$ ). The main binding point for IL-22 is the chain of its proper receptor - the IL-22R1 and the strength of the binding is increased by the IL-10 receptor chain, which stabilizes the interleukinreceptor complex. The STAT3 pathway is activated once the IL-22 binds to the receptor ${ }^{5}$.

Co-stimulation with IL-1 $\beta$ and IL-23 was found to promote IL-22 in mast cell progenitors ${ }^{6}$. While concomitant stimulation of Th17 by IL-17, IL-21 and IL-23 results in secretion of a mixture of cytokines, including IL-22 ( ref. $\left.^{7,8}\right)$. Although various lymphocyte subpopulations may differently regulate IL-22 secretion e.g. among the $\gamma \delta$ T cells it can be also stimulated by TLRs, IL-23 seems crucial for this process among various cell subsets ${ }^{8}$. The production of IL-22 may be decreased by the stimulation of c-Maf (ref. ${ }^{9}$ ) and probably also AHR $\left(\right.$ ref. $\left.^{10}\right)$. The latter most probably depends on the ligand used. Diesel exhaust particle polycyclic aromatic hydrocarbons were found to significantly promote IL-22 production by peripheral blood mononuclear cells in asthmatic patients ${ }^{11}$. Similarly, IL-22 production by innate lymphoid cells in a murine model of hepatitis was observed to be up-regulated by AHR and ROR $\gamma \mathrm{T}\left(\right.$ ref. $\left.^{12}\right)$. Moreover, expression of IL-22 is probably also increased in hypoxia in an HIF- $1 \alpha$-dependent mechanism ${ }^{13}$. An in-depth summary of IL-22 secretion regulation can be found in Dudakov et al. ${ }^{8}$.

IL-22 is involved in a number of processes - both physiological and pathological. It is probably involved in the pathogenesis of atopic dermatitis and asthma ${ }^{14}$. Its level is increased in an animal model of rheumatoid arthritis ${ }^{15}$ and IL-22 along with IL-4 may be important during pregnancy ${ }^{16}$. It is also important for proper regeneration of the intestinal epithelium ${ }^{17,18}$ and maintenance of the intestinal barrier ${ }^{19}$. IL-22 is also considered an important cancer-promoting cytokine ${ }^{20}$.

The serum IL-22 level is increased during relapse in relapsing-remitting MS patients compared to healthy controls, in patients with remission and those with primary progressive MS (ref. ${ }^{21}$ ). Similarly, an increase in $\mathrm{CD}^{+} \mathrm{IL}-22^{+}$percentage in peripheral blood was observed by $\mathrm{N}$. Muls et al. during relapse when compared to remission $^{22}$. Similarly, the Th22 percentage in peripheral blood was found to be higher in MS patients than healthy 


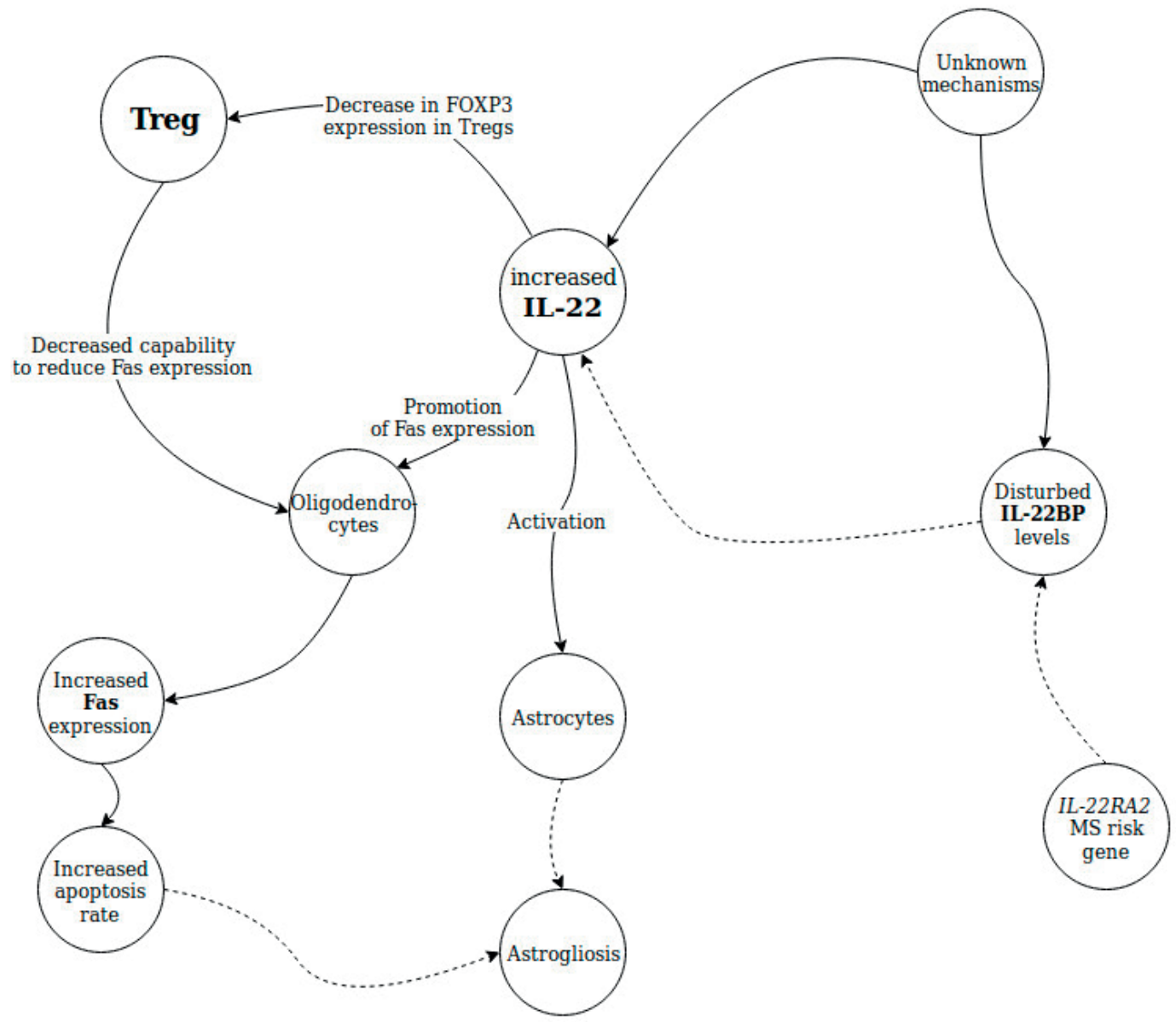

Fig. 1. The role of IL-22 in the course of MS is still ambiguous and not fully understood. This scheme shows the experimentally-proven (continued line) and hypothetical (dashed line) effects of IL-22 in MS.

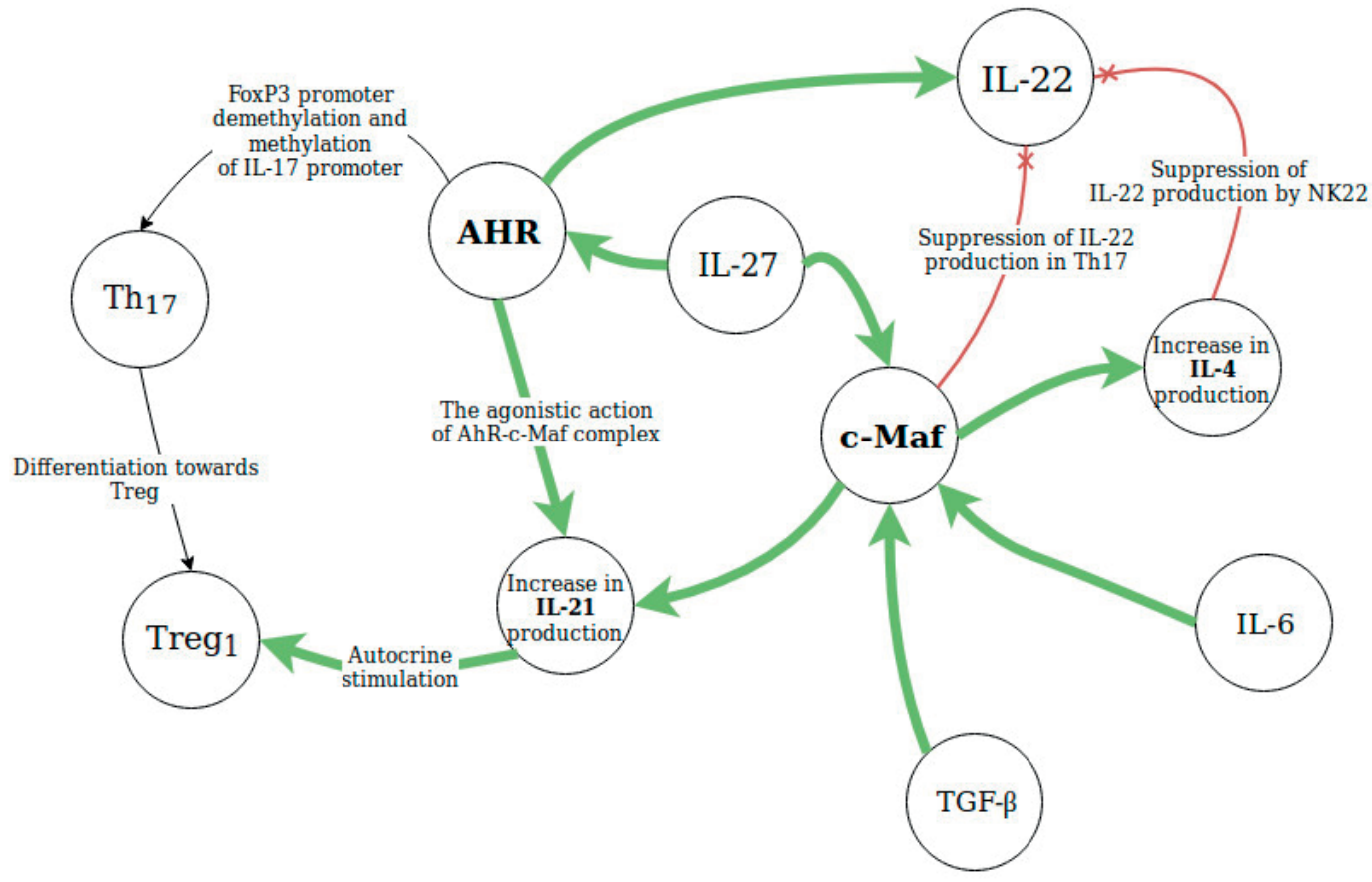

Fig. 2. The scheme shows the relation between IL-22, AHR and c-Maf. The demethylation of FoxP3 and methylation of IL-17 promoter requires prior proper AHR stimulation e.g. by FICZ. On the other hand, activated by Notch, AHR along with STAT3 and ROR $\gamma$ T potently promote IL-22 secretion in Th17 cells. Similarly activation of AHR by FICZ increases IL-22 production. Bold green line indicate positive influence (induction or activation) while red line negative influence (supression). 
controls $^{23-25}$. Nicol et al. described a novel subpopulation of $\mathrm{T}$ cytotoxic lymphocytes - Tc17 with intermediate expression of CD161 as another source of IL-22 in MS patients ${ }^{26}$. Increase in serum IL-22 level and Th22 percentage were also confirmed in MS and neuromyelitis optica $^{27}$. The increase in IL-22 and IL-17 levels corresponds to fresh lesions in the central nervous system during MS $\left(\right.$ ref. $\left.{ }^{28}\right)$. Perriard et al. showed that IL-22 is present in both white and gray matter in healthy controls and MS patients and that it is also involved in the stimulation of astrocyte survival $^{21}$. On the other hand, Zhen et al. noted that stimulation of oligodendrocytes with IL-22 leads to increased Fas expression, which may result in increased apoptosis ${ }^{23}$. This is probably attenuated in healthy individuals by the Treg cells as an in vitro study of mouse Treg cells revealed their potential to lower the overexpression of Fas in oligodendrocytes. This effect was, however, not observed in the case of Treg cells from mice with EAE. This may be related to decreased level of FOXP3 expression in those cells, which is also probably related to IL-22 ( ref. $^{23}$ ).

Tahrali et al. noticed an increased percentage of IL22-producing NK cells in MS patients. In further in vitro tests, they observed that stimulation with IL-4 had nearly no effect on the IL-22 secretion by those cells - despite the fact that in healthy subjects IL-4 stimulation causes NK22 cell differentiation into an NK2 subpopulation and cessation of IL-22 secretion ${ }^{29}$. The level of IL-22 in the central nervous system during the course of EAE rises with a peak at the time-point of maximal disability and a significant decrease during remission ${ }^{30}$. Similar results were obtained by Kreymborg et al., who studied IL-22 expression in the central nervous system infiltrating lymphocytes in various phases of EAE (ref. ${ }^{31}$ ). IL-22 turned out to be unnecessary for EAE to develop - IL-22-genedeficient mice developed the disease similarly to wild type mice $^{31}$. In an in vitro investigation stimulation of lymphocytes from MS patients with melatonin led to a significant decrease in IL-22 expression ${ }^{32}$. This appears to be related to a phenomenon observed by Scandinavian scientists. They noted the increased risk of MS in those who worked night-shifts at a young age. That effect was ascribed to disturbance in the circadian rythm ${ }^{33,34}$. Another potential regulator of IL-22 secretion is bacterial lipopolysaccharide (LPS) - by the regulation of dendritic cell function it was observed to lower the expression of IL-22 along with IL-17A, IL-17F and IL-21 in Th lymphocytes ${ }^{35}$.

Physical and mental fatigue is a major symptom of MS. According to Rohit Bakshi, it is even the most prevalent one, and for $40 \%$ of patients also the one which most limits their daily activity ${ }^{36}$. The occurrence and intensity of fatigue are linked, among other factors, to the influence of various cytokines, most commonly TNF- $\alpha$ and IFN- $\gamma$ $\left(\right.$ ref. ${ }^{37}$ ). An initial study by a Brazilian team revealed a possible link of fatigue with IL-22 (ref. ${ }^{38}$ ). An in vitro study revealed higher potential for IL-22 production by lymphocytes from MS patients with significant fatigue compared to those without fatigue. The same team in another study noted that a 12-week training not only lowered the fatigue, but also the potential for IL-22 production $^{39}$. Further studies are needed for an in-depth understanding of this phenomenon.

The deregulation of IL-22 levels may be related both to the change in IL-22 expression and in its serum binding protein - the IL-22BP (IL-22RA2). IL-22 as the only cytokine of the IL-10-family has its own soluble binding protein and, moreover, it has higher affinity for IL-22 than the membrane receptor ${ }^{40}$. This indicates the importance of IL-22 level regulation and the potential risk related to the disturbance in IL-22 level.

No significant difference in serum IL-22BP level was noted in MS patients, but an increase in its mRNA was observed in monocytes and dendritic cells ${ }^{21}$. It seems that during relapse IL-22 escapes the control of IL-22BP. Moreover, some SNPs of the gene for the IL-22 soluble receptor (IL22RA2) are probably linked to the increased risk of both EAE and MS (ref. ${ }^{41}$ ). At the same time, another study revealed that IL22ra2-deficient mice showed a milder course of EAE, which suggests a protective role of IL-22 as well as potential negative effects of an increased IL-22BP serum level ${ }^{42}$.

\section{c-Maf}

c-Maf is a transcription factor with numerous functions e.g. it is necessary for the TGF- $\beta$ mediated suppression of IL-22 production in Th17 (ref. ${ }^{9}$ ) or along with Sox 5 for the expression of ROR $\gamma \mathrm{T}$ in Th17 cells ${ }^{43}$.

The c-Maf synthesis is mediated by IL-6, which, in turn, leads to an increased IL-21 production by the activation of IL-21 promoter and CNS-2 (ref. ${ }^{44}$ ). IL-21 stimulates IL-22 expression in Th lymphocytes ${ }^{45}$. As previously mentioned, TGF- $\beta$ causes inhibition of the described mechanism ${ }^{44}$. Transgenic mice lacking c-Maf have a significantly lower IL-21 expression than wild-type mice ${ }^{46}$.

C-Maf may act agonistically with AHR. The IL-27induced AHR joins c-Maf, which leads to the activation of IL-10 and IL-21 promoters in Treg 1 lymphocytes ${ }^{47}$. Moreover, IL-27 by c-Maf stimulation also increases IL21 synthesis. By autocrine signaling, the latter stimulates and promotes the survival of IL-10-secreting Treg1 (ref. ${ }^{48}$ ). Increased level of IL-27 and IL-33 in the central nervous

Table 1. Selected AHR ligands divided into agonists, antagonists and selective modulators.

\begin{tabular}{llc}
\hline Type & Molecules & References \\
\hline Agonists & TCDD, $\beta$-NF ( $\beta$-Naphthoflavone), FICZ (6-Formylindolo[3,2-b]carbazole), & $56,71,73-75$ \\
& ITE (Methyl 2-(1H-indole-3-carbonyl)-1,3-thiazole-4-carboxylate) & 76 \\
Antagonists & GNF-351 & 77 \\
Selective modulators & SGA-360 & 77 \\
\hline
\end{tabular}


system seems to alleviate the symptoms of EAE (ref. ${ }^{49}$ ). Both c-Maf and AHR seems to be partially regulated by PTIP - under no PTIP influence the production of IL22 rises while that of IL-17 decreases ${ }^{50}$. Generally, c-Maf seems to block the expression of IL-22 in Th17, while AHR along with ROR $\gamma \mathrm{T}$ promote it $^{9,51}$. On the other hand, as previously mentioned, c-Maf along with Sox 5 promotes expression of ROR $\gamma \mathrm{T}$ in $\mathrm{Th} 17$, thus indirectly promoting IL-22 production ${ }^{43}$.

Besides, c-Maf promotes IL-4 secretion by joining its promotor $^{52-54}$. Nevertheless, c-Maf can not freely regulate any of those cytokines; the exact type of phosphorylation of c-Maf determines which one is affected ${ }^{52}$. In the case of IL-4 regulation, the degree of stimulation positively correlates with the phosphorylation level of tyrosine in cMaf, namely $\operatorname{Tyr}(21), \operatorname{Tyr}(92), \operatorname{Tyr}(131)$ (ref. $\left.{ }^{53}\right)$. Currently, there is no data on the expression of c-Maf in MS patients.

\section{AHR}

AHR is a transcription factor involved in the differentiation of Th17 and Treg cells, it is also one of the transcription factors involved in regulation of IL-22 production $^{51}$. TCDD, a strong AHR agonist, is one of the most commonly used molecules in studies involving the AHR function. In a mouse model of Crohn disease, the application of TCDD led to strong symptom attenuation due to induction of Treg and suppression of Th17 lymphocytes $^{55}$. The effect is related to epigenetic changes increased methylation of IL-17 promoter and concomitant demethylation of FOXP3 promoter. That action was also proved in another study on mouse model of Crohn disease by Benson and Shepard ${ }^{56}$ as well as in autoimmune uveitis by Zhang et al. ${ }^{57}$. Quintana et al. in an EAE study discovered that TCDD-mediated activation of AHR leads to the attenuation of symptoms, which is probably related to the observed Th17/Treg balance shift towards Treg, while the use of FICZ, another AHR agonist, had the opposite effect $^{58}$. Similarly, Hanieh and Alzahrani observed EAE symptom attenuation after TCDD-mediated AHR activation and ascribed it to the increased miR-132 expression in Th lymphocytes ${ }^{59}$. On the other hand, the effect of both FICZ and TCDD may depend also on other factors like the route of administration and immune cells affected ${ }^{60}$ It is worth noting that miR-132 performs opposite functions in B lymphocytes - it increases the production of pro-inflammatory cytokines and therefore may escalate EAE or MS symptoms ${ }^{61}$. It was also noticed that AHR is involved in DHEA-mediated amelioration of EAE symptoms $^{62}$. On the other hand, AHR-deficient mice develop milder course of EAE (ref. ${ }^{63}$ ).

AHR is an important regulator of IL-22 transcription $^{51}$. In fact, it seems to be essential for IL-22 production by $\gamma \delta \mathrm{T}\left(\right.$ ref. $\left.^{64}\right)$, Th22 and Th17 (ref. ${ }^{65}$ ) cells. Activation by FICZ leads to a significant upregulation of production ${ }^{10}$. Moreover, environmental pollutants like polycyclic aromatic hydrocarbons may upregulate the activity of AHR by inhibition of cytochrome P4501, which is responsible for FICZ cleavage ${ }^{66}$. Another important site for AHRrelated immunoregulation is the intestines, where the commensal bacteria produce significant amounts of AHR ligands and therefore regulate the immune system ${ }^{67}$. This is especially important as the intestinal microbiota may be involved in the pathogenesis of multiple sclerosis ${ }^{68}$.

The literal effect depends on the type of AHR ligand. These are divided into three groups - agonists, antagonists and selective modulators (Table 1). Such a division is related to the activation or inhibition of two possible pathways - X/DRE and non-X/DRE. An agonist activates both, an antagonist inhibits both, and a selective modulator activates one while blocking the other. The X/ DRE pathway is related to the relocation of AHR to the nucleoplasm and its direct influence on the expression of DNA. The activation of non-X/DRE leads to direct protein-protein interaction, and only indirectly regulates the expression of DNA. AHR antagonists cause the Treg/ Th17 balance shift towards Treg, while agonists trigger opposite effects ${ }^{69}$. Nevertheless, there are some known exceptions; the before-mentioned TCDD, despite being an agonist, causes a Th17/Treg balance shift towards Treg. In a study by Gagliani et al., concomitant stimulation with TGF- $\beta 1$ and FICZ causes the differentiation of Th17 into Treg1 $\left(\right.$ ref. $\left.^{70}\right)$. AHR may not be necessary for the effect, but it was also noted that AHR antagonists cause significant decrease in the speed of the process. The use of ITE, another AHR agonist, also causes an increase in Treg percentage ${ }^{71}$. It appears that the exact effect of AHR agonist depends on the dose and time of the AHR activation. A low dose and short period of activation may lead to the expansion of Th17 lymphocytes, while larger dose and longer period cause an increase in Treg cells ${ }^{72}$.

\section{CONCLUSION}

Despite numerous studies, the exact role of IL-22 in the pathogenesis of MS is still unknown. The expression and function of c-Maf in MS have not been studied. It seems that the functions of c-Maf and AHR are at least partially connected with IL-22, as both directly or indirectly influence the regulation of IL-22 expression. This possible connection has never been studied in MS, either.

\section{Search strategy and selection criteria}

The aim of the paper was to summarise the knowledge of IL-22 involvement in multiple sclerosis and the possible link between IL-22 and two transcription factors - AHR and c-Maf. Therefore, Pubmed and Scopus were searched for all relevant studies. Following keywords were used: "MS", "multiple sclerosis", "EAE", "experimental autoimmune encephalomyelitis", "IL-22", "interleukin 22", "AHR", "c-Maf" and the mixtures thereof. The initial search was performed in 2017 and was then updated in 2018 and in January 2019. Only peer reviewed papers written in English were included. 


\section{ABBREVIATIONS}

AHR, Aryl hydrocarbon receptor; c-Maf, Transcription factor Maf; $\mathrm{CD}$, Cluster of differentiation (designation); CNS-2, Conserved noncoding sequence-2; DHEA, Dehydroepiandrosterone; EAE, Experimental autoimmune encephalomyelitis; FICZ, 6-formylindolo[3,2-b] carbazole; FOXP3, Forkhead box p3; HIF-1 $\alpha$, Hypoxiainducible factor $1 \alpha$; IFN- $\gamma$, Interferon $\gamma$; IL, Interleukin; IL-10R2, Interleukin 10 receptor subunit 2; IL-22BP/ IL-22RA2, Interleukin 22 binding protein/soluble receptor; IL-22R1, Interleukin 22 receptor subunit 1; Lti, Lymphoid tissue inducer cell; miR-132, microRNA-132; MS, Multiple sclerosis; NK, Natural killer cell; NKT, Natural killer T cell; PTIP, Pax transactivation domaininteracting protein; ROR $\gamma \mathrm{T}$, Retinoic acid receptor-related orphan receptor gamma; SNP, Single nucleotide polymorphism; Sox5, Sex-determining region Y (SRY)-Related high mobility group (HMG)-box 5; STAT3, Signal transducer and activator of transcription 3; Tc, T cytotoxic lymphocyte; TCDD, 2,3,7,8-tetrachlorodibenzo-p-dioxin; TGF- $\beta$, Tumour growth factor $\beta$; Th, T helper lymphocyte; TNF- $\alpha$, Tumor necrosis factor $\alpha$; Treg, T regulatory lymphocyte; Tyr, Tyrosine; X/DRE, Xenobiotic or dioxin response elements.

Author contributions: MKZ, WK, MS, JR, ABJ: literature search, MKZ, WK, ABJ: manuscript writing, MKZ, WK, MS, JR, ABJ: manuscript review and editing, MKZ figures, MKZ, WK, MS, JR, ABJ: final approval of the version to be published.

Conflict of interest statement: The authors state that there are no conflicts of interest regarding the publication of this article.

\section{REFERENCES}

1. Tahmasebinia F, Pourgholaminejad A. The role of Th17 cells in autoinflammatory neurological disorders. Prog Neuropsychopharmaco Biol Psychiatry 2017;79:408-16.

2. Tian T, Yu S, Ma D. Th22 and related cytokines in inflammatory and autoimmune diseases. Expert Opin Ther Targets 2013;17:113-25.

3. Fard NA, Azizi G, Mirshafiey A. The Potential Role of T Helper Cell 22 and IL-22 in Immunopathogenesis of Multiple Sclerosis. Innov Clin Neurosci 2016;13:30-6

4. Li J, Tomkinson KN, Tan XY, Wu P, Yan G, Spaulding V, Deng B, AnnisFreeman B, Heveron K, Zollner R, De Zutter G, Wright JF, Crawford TK, Liu W, Jacobs KA, Wolfman NM, Ling V, Pittman DD, Veldman GM, Fouser LA. Temporal associations between interleukin 22 and the extracellular domains of IL-22R and IL-10R2. Int Immunopharmaco 2004;4:693-708.

5. Nagalakshmi ML, Rascle A, Zurawski S, Menon S, de Waal Malefyt R. Interleukin-22 activates STAT3 and induces IL-10 by colon epithelial cells. Int Immunopharmacol 2004;4:679-91.

6. Lee $Y$, Kumagai Y, Jang MS, Kim JH, Yang BG, Lee EJ, Kim YM, Akira $\mathrm{S}$, Jang MH. Intestinal Lin- C-Kit+ NKp46- CD4- population strongly produces IL-22 upon IL-1 $\beta$ stimulation. J Immunol 2013;190:5296305.

7. Zarobkiewicz MK, Kowalska W, Roliński J, Bojarska-Junak AA. $\gamma \delta$ T lymphocytes in the pathogenesis of multiple sclerosis and experimental autoimmune encephalomyelitis. J Neuroimmunol 2019;330:67-73.
8. Dudakov JA, Hanash AM, van den Brink MRM. Interleukin-22: immunobiology and pathology. Annu Rev Immunol 2015;33:747-85.

9. Rutz S, Noubade R, Eidenschenk C, Ota N, Zeng W, Zheng Y, Hackney J, Ding J, Singh H, Ouyang W. Transcription factor c-Maf mediates the TGF- $\beta$-dependent suppression of IL-22 production in TH17 cells. Nat Immun 2011;12:1238-45.

10. McAleer JP, Fan J, Roar B, Primerano DA, Denvir J. Cytokine Regulation in Human CD4 T Cells by the Aryl Hydrocarbon Receptor and Gq-Coupled Receptors. Sci Rep 2018;8:10954.

11. Plé $C$, Fan $Y$, Ait Yahia S, Vorng H, Everaere L, Chenivesse $C$, Balsamelli J, Azzaoui I, de Nadai P, Wallaert B, Lazennec G, Tsicopoulos A. Polycyclic aromatic hydrocarbons reciprocally regulate IL-22 and IL-17 cytokines in peripheral blood mononuclear cells from both healthy and asthmatic subjects. PLoS ONE 2015;10:e0122372.

12. Abe H, Kimura A, Tsuruta S, Fukaya T, Sakaguchi R, Morita R, Sekiya T, Shichita T, Chayama K, Fujii-Kuriyama Y, Yoshimura A. Aryl hydrocarbon receptor plays protective roles in ConA-induced hepatic injury by both suppressing IFN- $\gamma$ expression and inducing IL-22. Int Immunol 2014;26:129-37.

13. Budda SA, Girton A, Henderson JG, Zenewicz LA. Transcription Factor HIF-1 a Controls Expression of the Cytokine IL-22 in CD4 T Cells. J Immunol 2016;197:2646-52.

14. Leyva-Castillo JM, Yoon J, Geha RS. IL-22 promotes allergic airway inflammation in epicutaneously sensitized mice. J Allergy Clin Immunol 2019;143:619-630.e7.

15. Wang B, Zhao P, Zhou Y, Meng L, Zhu W, Jiang C, Wang L, Cai Y, Lu S, Hou W. Increased expression of Th17 cytokines and interleukin-22 correlates with disease activity in pristane-induced arthritis in rats. PLOS ONE 2017;12:e0188199.

16. Logiodice F, Lombardelli L, Kullolli O, Haller H, Maggi E, Rukavina D, Piccinni M-P. Decidual Interleukin-22-Producing CD4+T Cells (Th17/ Th0/IL-22+ and Th17/Th2/IL-22+, Th2/IL-22+, Th0/IL-22+), Which Also Produce IL-4, Are Involved in the Success of Pregnancy. Int J Mol Sci 2019;20:428.

17. Hou Q, Ye L, Liu H, Huang L, Yang Q, Turner J, Yu Q. Lactobacillus accelerates ISCs regeneration to protect the integrity of intestinal mucosa through activation of STAT3 signaling pathway induced by LPLs secretion of IL-22. Cell Death Differ 2018;25:1657-70.

18. Fang L, Pang Z, Shu W, Wu W, Sun M, Cong Y, Liu Z. Anti-TNF Therapy Induces CD4+ T-Cell Production of IL-22 and Promotes Epithelial Repairs in Patients with Crohn's Disease. Inflamm Bowel Dis 2018;24:1733-44.

19. Wang J, Wang $P$, Tian H, Tian F, Zhang Y, Zhang L, Gao X, Wang X. Aryl hydrocarbon receptor/IL-22/Stat3 signaling pathway is involved in the modulation of intestinal mucosa antimicrobial molecules by commensal microbiota in mice. Innate Immun-London 2018;24:297306.

20. Voigt C, May P, Gottschlich A, Markota A, Wenk D, Gerlach I, Voigt S, Stathopoulos GT, Arendt KAM, Heise C, Rataj F, Janssen KP, Königshoff M, Winter H, Himsl I, Thasler WE, Schnurr M, Rothenfußer S, Endres S, Kobold S. Cancer cells induce interleukin-22 production from memory CD4+T cells via interleukin-1 to promote tumor growth. P Natl Acad Sci USA 2017;114:12994-9.

21. Perriard G, Mathias A, Enz L, Canales M, Schluep M, Gentner M, Schaeren-Wiemers N, Du Pasquier RA. Interleukin-22 is increased in multiple sclerosis patients and targets astrocytes. J Neuroinflammation 2015;12:119.

22. Muls N, Nasr Z, Dang HA, Sindic C, van Pesch V. IL-22, GM-CSF and IL-17 in peripheral CD4+ T cell subpopulations during multiple sclerosis relapses and remission. Impact of corticosteroid therapy. PLoS ONE 2017;12:e0173780.

23. Zhen J, Yuan J, Fu Y, Zhu R, Wang M, Chang H, Zhao Y, Wang D, Lu Z. IL-22 promotes Fas expression in oligodendrocytes and inhibits FOXP3 expression in T cells by activating the NF-KB pathway in multiple sclerosis. Mol Immunol 2017;82:84-93.

24. Tao Y, Zhang X, Zivadinov R, Dwyer MG, Kennedy C, Bergsland N, Ramasamy D, Durfee J, Hojnacki D, Hayward B, Dangond F, Weinstock-Guttman B, Markovic-Plese S. Immunologic and MRI markers of the therapeutic effect of IFN- $\beta$ - $1 \mathrm{a}$ in relapsing-remitting MS. Neurol Neuroimmunol Neuroinflamm 2015;2:e176.

25. Rolla S, Bardina V, De Mercanti S, Quaglino P, De Palma R, Gned D, Brusa D, Durelli L, Novelli F, Clerico M. Th22 cells are expanded in multiple sclerosis and are resistant to IFN- $\beta$. J Leukoc Biol 2014;96:1155-64 
26. Nicol B, Salou M, Vogel I, Garcia A, Dugast E, Morille J, Kilens S Charpentier E, Donnart A, Nedellec $S$, Jacq-Foucher M, Le Frère F, Wiertlewski S, Bourreille A, Brouard S, Michel L, David L, Gourraud PA, Degauque N, Nicot AB, Berthelot L, Laplaud DA. An intermediate level of CD161 expression defines a novel activated, inflammatory, and pathogenic subset of CD8+T cells involved in multiple sclerosis. J Autoimmun 2017;88:61-74.

27. Xu W, li R, Dai Y, Wu A, Wang H, Cheng C, Qiu W, Lu Z, Zhong X, Shu Y, Kermode AG, Hu X. IL-22 secreting CD4+ T cells in the patients with neuromyelitis optica and multiple sclerosis. J Neuroimmunol 2013;261:87-91.

28. Wing AC, Hygino J, Ferreira TB, Kasahara TM, Barros PO, Sacramento PM, Andrade RM, Camargo S, Rueda F, Alves-Leon SV, Vasconcelos CC, Alvarenga R, Bento CAM. Interleukin-17- and interleukin-22-secreting myelin-specific CD4 ${ }^{+} T$ cells resistant to corticoids are related with active brain lesions in multiple sclerosis patients. Immunology 2016;147:212-20.

29. Tahrali I, Kucuksezer UC, Altintas A, Uygunoglu U, Akdeniz N, AktasCetin E, Deniz G. Dysfunction of CD3-CD16+CD56dimand CD3CD16-CD56brightNK cell subsets in RR-MS patients. Clin Immunol 2018;193:88-97.

30. Almolda B, Costa M, Montoya M, González B, Castellano B. Increase in Th17 and T-reg Lymphocytes and Decrease of IL22 Correlate with the Recovery Phase of Acute EAE IN Rat PLOS ONE 2011;6:e27473.

31. Kreymborg K, Etzensperger R, Dumoutier L, Haak S, Rebollo A, Buch T, Heppner FL, Renauld JC, Becher B. IL-22 is expressed by Th17 cells in an IL-23-dependent fashion, but not required for the development of autoimmune encephalomyelitis. J Immunol 2007;179:8098104.

32. Álvarez-Sánchez N, Cruz-Chamorro I, Díaz-Sánchez M, SarmientoSoto H, Medrano-Campillo P, Martínez-López A, Lardone PJ, Guerrero $\mathrm{JM}$, Carrillo-Vico A. Melatonin reduces inflammatory response in peripheral T helper lymphocytes from relapsing-remitting multiple sclerosis patients. J Pineal Res 2017;63(4). doi: 10.1111/jpi.12442

33. Gustavsen S, Søndergaard HB, Oturai DB, Laursen B, Laursen JH, Magyari M, Ullum H, Larsen MH, Sellebjerg F, Oturai AB. Shift work at young age is associated with increased risk of multiple sclerosis in a Danish population. Mult Scler Relat Disord 2016;9:104-9.

34. Hedström AK, Åkerstedt T, Hillert J, Olsson T, Alfredsson L. Shift work at young age is associated with increased risk for multiple sclerosis. Ann Neurol 2011;70:733-41.

35. Zhou F, Ciric B, Zhang G-X, Rostami A. Immunotherapy using lipopolysaccharide-stimulated bone marrow-derived dendritic cells to treat experimental autoimmune encephalomyelitis. Clin Exp Immunol 2014;178:447-58.

36. Bakshi R. Fatigue associated with multiple sclerosis: diagnosis, impact and management. Mult Scler 2003;9:219-27.

37. Braley TJ, Chervin RD. Fatigue in Multiple Sclerosis: Mechanisms, Evaluation, and Treatment. Sleep 2010;33:1061-7.

38. Alvarenga-Filho H, Salles M, Hygino J, Ferreira TB, Sacramento PM, Monteiro C, Vasconcelos CCF, Alvarenga RMP, Bento CAM. Fatigue favors in vitro Th1 and Th17-like cell expansion and reduces corticoid sensitivity in MS patients. J Neuroimmunol 2017;303:81-9.

39. Alvarenga-Filho H, Sacramento PM, Ferreira TB, Hygino J, Abreu JEC Carvalho SR, Wing AC, Alvarenga RMP, Bento CAM. Combined exercise training reduces fatigue and modulates the cytokine profile of T-cells from multiple sclerosis patients in response to neuromediators. J Neuroimmunol 2016;293:91-9.

40. Xin N, Namaka MP, Dou C, Zhang Y. Exploring the role of interleukin-22 in neurological and autoimmune disorders. Int Immunopharmacol 2015;28:1076-83.

41. Beyeen AD, Adzemovic MZ, Ockinger J, Stridh P, Becanovic K Laaksonen $\mathrm{H}$, Lassmann $\mathrm{H}$, Harris RA, Hillert J, Alfredsson L, Celius EG, Harbo HF, Kockum I, Jagodic M, Olsson T. IL-22RA2 Associates with Multiple Sclerosis and Macrophage Effector Mechanisms in Experimental Neuroinflammation. J Immunol 2010;185:6883-90.

42. Laaksonen $H$, Guerreiro-Cacais AO, Adzemovic MZ, Parsa $R$ Zeitelhofer $M$, Jagodic $M$, Olsson T. The multiple sclerosis risk gene IL22RA2 contributes to a more severe murine autoimmune neuroinflammation. Genes Immun 2014;15:457-65.

43. Tanaka S, Suto A, Iwamoto T, Kashiwakuma D, Kagami S-I, Suzuki K, Takatori H, Tamachi T, Hirose K, Onodera A, Suzuki J, Ohara O, Yamashita M, Nakayama T, Nakajima H. Sox5 and c-Maf cooperatively induce Th17 cell differentiation via RORyt induction as downstream targets of Stat3. J Exp Med 2014;211:1857-74.
44. Hiramatsu Y, Suto A, Kashiwakuma D, Kanari H, Kagami S -i., Ikeda K, Hirose K, Watanabe N, Grusby MJ, Iwamoto I, Nakajima H. c-Maf activates the promoter and enhancer of the IL-21 gene, and TGFinhibits c-Maf-induced IL-21 production in CD4+ T cells. J Leukoc Biol 2010;87:703-12.

45. Yeste A, Mascanfroni ID, Nadeau M, Burns EJ, Tukpah A-M, Santiago A, Wu C, Patel B, Kumar D, Quintana FJ. IL-21 induces IL-22 production in CD4+ T cells. Nat Commun 2014;5:3753.

46. Bauquet AT, Jin H, Paterson AM, Mitsdoerffer M, Ho IC, Sharpe AH, Kuchroo VK. The costimulatory molecule ICOS regulates the expression of c-Maf and IL-21 in the development of follicular T helper cells and TH-17 cells. Nat Immun 2009;10:167-75.

47. Apetoh L, Quintana FJ, Pot C, Joller N, Xiao S, Kumar D, Burns EJ, Sherr $\mathrm{DH}$, Weiner $\mathrm{HL}$, Kuchroo VK. The aryl hydrocarbon receptor interacts with c-Maf to promote the differentiation of type 1 regulatory T cells induced by IL-27. Nat Immun 2010;11:854-61.

48. Pot C, Jin H, Awasthi A, Liu SM, Lai C-Y, Madan R, Sharpe AH, Karp CL, Miaw S-C, Ho I-C, Kuchroo VK. Cutting Edge: IL-27 Induces the Transcription Factor c-Maf, Cytokine IL-21, and the Costimulatory Receptor ICOS that Coordinately Act Together to Promote Differentiation of IL-10-Producing Tr1 Cells. J Immunol 2009;183:797801.

49. Jafarzadeh A, Mohammadi-Kordkhayli M, Ahangar-Parvin R, Azizi V, Khoramdel-Azad H, Shamsizadeh A, Ayoobi A, Nemati M, Hassan ZM, Moazeni SM, Khaksari M. Ginger extracts influence the expression of IL-27 and IL-33 in the central nervous system in experimental autoimmune encephalomyelitis and ameliorates the clinical symptoms of disease. J Neuroimmunol 2014;276:80-8.

50. Assis PA, Ueha S, Schaller M, Kunkel SL. 8: Epigenetic regulation of Th-17 differentiation. Cytokine 2013;63:244.

51. Rutz S, Eidenschenk C, Ouyang W. IL-22, not simply a Th17 cytokine. Immunol Rev 2013;252:116-32.

52. Liu CC, Lai CY, Yen WF, Lin YH, Chang HH, Tai TS, Lu YJ, Tsao HW, Ho IC, Miaw SC. Reciprocal Regulation of C-Maf Tyrosine Phosphorylation by Tec and Ptpn22. Akiyama T, editor. PLOS ONE 2015;10:e0127617.

53. Lai CY, Lin SY, Wu CK, Yeh LT, Sytwu HK, Miaw SC. Tyrosine Phosphorylation of c-Maf Enhances the Expression of IL-4 Gene. J Immunol 2012;189:1545-50.

54. Ho IC, Hodge MR, Rooney JW, Glimcher LH. The proto-oncogene c-maf is responsible for tissue-specific expression of interleukin-4. Cell 1996;85:973-83.

55. Singh NP, Singh UP, Singh B, Price RL, Nagarkatti $M$, Nagarkatti PS. Activation of Aryl Hydrocarbon Receptor (AhR) Leads to Reciprocal Epigenetic Regulation of FoxP3 and IL-17 Expression and Amelioration of Experimental Colitis. Stoddart CA, editor. PLoS ONE 2011;6:e23522.

56. Benson JM, Shepherd DM. Aryl Hydrocarbon Receptor Activation by TCDD Reduces Inflammation Associated with Crohn's Disease. Toxicol Sci 2011;120:68-78.

57. Zhang L, Ma J, Takeuchi M, Usui Y, Hattori T, Okunuki Y, Yamakawa N, Kezuka T, Kuroda M, Goto H. Suppression of Experimental Autoimmune Uveoretinitis by Inducing Differentiation of Regulatory T Cells via Activation of Aryl Hydrocarbon Receptor. Invest Ophthalmol Vis Sci 2010;51:2109.

58. Quintana FJ, Basso AS, Iglesias AH, Korn T, Farez MF, Bettelli E, Caccamo M, Oukka M, Weiner HL. Control of Treg and TH17 cell differentiation by the aryl hydrocarbon receptor. Nature 2008;453:6571.

59. Hanieh H, Alzahrani A. MicroRNA-132 suppresses autoimmune encephalomyelitis by inducing cholinergic anti-inflammation: a new Ahr-based exploration. Eur J Immunol 2013;43:2771-82.

60. Duarte JH, Di Meglio P, Hirota K, Ahlfors H, Stockinger B. Differential Influences of the Aryl Hydrocarbon Receptor on Th17 Mediated Responses in vitro and in vivo. PLoS ONE 2013;8:e79819.

61. Miyazaki Y, Li R, Rezk A, Misirliyan H, Moore C, Farooqi N, Solis M, Goiry LG, de Faria Junior O, Dang VD, Colman D, Dhaunchak AS, Antel J, Gommerman J, Prat A, Fillatreau S, Bar-Or A, CIHR/MSSC New Emerging Team Grant in Clinical Autoimmunity, MSSRF Canadian B cells in MS Team. A novel microRNA-132-sirtuin-1 axis underlies aberrant B-cell cytokine regulation in patients with relapsing-remitting multiple sclerosis [corrected]. PLoS ONE 2014;9:e105421.

62. Aggelakopoulou M, Kourepini E, Paschalidis N, Simoes DCM, Kalavrizioti D, Dimisianos N, Papathanasopoulos P, Mouzaki A, Panoutsakopoulou V. ER $\beta$-Dependent Direct Suppression of Human and Murine Th17 Cells and Treatment of Established Central Nervous 
System Autoimmunity by a Neurosteroid. J Immunol 2016;197:2598609.

63. de Lima KA, Donate PB, Talbot J, Davoli-Ferreira M, Peres RS, Cunha TM, Alves-Filho JC, Cunha FQ. TGF $\beta 1$ signaling sustains aryl hydrocarbon receptor (AHR) expression and restrains the pathogenic potential of TH17 cells by an AHR-independent mechanism. Cell Death Dis 2018;9(11):1130. doi: 10.1038/s41419-018-1107-7

64. Martin B, Hirota K, Cua DJ, Stockinger B, Veldhoen M. Interleukin-17Producing $\gamma \delta T$ Cells Selectively Expand in Response to Pathogen Products and Environmental Signals. Immunity 2009;31:321-30.

65. Trifari S, Kaplan CD, Tran EH, Crellin NK, Spits H. Identification of a human helper $\mathrm{T}$ cell population that has abundant production of interleukin 22 and is distinct from $\mathrm{TH}-17, \mathrm{TH} 1$ and $\mathrm{TH} 2$ cells. Nat Immun 2009;10:864-71.

66. Schiering C, Vonk A, Das S, Stockinger B, Wincent E. Cytochrome P4501-inhibiting chemicals amplify aryl hydrocarbon receptor activation and IL-22 production in T helper 17 cells. Biochem Pharmacol 2018;151:47-58.

67. Wheeler MA, Rothhammer V, Quintana FJ. Control of immune-mediated pathology via the aryl hydrocarbon receptor. J Biol Chem 2017;292:12383-9.

68. Castillo-Álvarez F, Marzo-Sola ME. Role of intestinal microbiota in the development of multiple sclerosis. Neurología (English Edition). 2017;32:175-84.

69. Mohinta S, Kannan AK, Gowda K, Amin SG, Perdew GH, August A. Differential Regulation of Th17 and T Regulatory Cell Differentiation by Aryl Hydrocarbon Receptor Dependent Xenobiotic Response Element Dependent and Independent Pathways. Toxicol Sci 2015;145:233-43.

70. Gagliani N, Amezcua Vesely MC, Iseppon A, Brockmann L, Xu H, Palm NW, de Zoete MR, Licona-Limón P, Paiva RS, Ching T, Weaver C, Zi X,
Pan X, Fan R, Garmire LX, Cotton MJ, Drier Y, Bernstein B, Geginat J, Stockinger B, Esplugues E, Huber S, Flavell RA. Th17 cells transdifferentiate into regulatory $T$ cells during resolution of inflammation. Nature 2015;523:221-5.

71. Abron JD, Singh NP, Mishra MK, Price RL, Nagarkatti M, Nagarkatti PS, Singh UP. An endogenous aryl hydrocarbon receptor ligand, ITE, induces regulatory $T$ cells and ameliorates experimental colitis. Am J Physiol Gastrointest Liver Physiol 2018;315:G220-30.

72. Ehrlich AK, Pennington JM, Bisson WH, Kolluri SK, Kerkvliet NI. TCDD, FICZ, and Other High Affinity AhR Ligands Dose-Dependently Determine the Fate of CD4+ T Cell Differentiation. Toxicol Sci 2018;161:310-20.

73. Carver LA, Jackiw V, Bradfield CA. The $90-\mathrm{kDa}$ heat shock protein is essential for Ah receptor signaling in a yeast expression system. J Biol Chem 1994;269:30109-12.

74. Jeong KT, Hwang SJ, Oh GS, Park JH. FICZ, a Tryptophan photoproduct, suppresses pulmonary eosinophilia and Th2-type cytokine production in a mouse model of ovalbumin-induced allergic asthma. Int Immunopharmacol 2012;13:377-85.

75. Song J, Clagett-Dame M, Peterson RE, Hahn ME, Westler WM, Sicinski RR, DeLuca HF. A ligand for the aryl hydrocarbon receptor isolated from lung. Proc Natl Acad Sci USA 2002;99:14694-9.

76. Smith KJ, Murray IA, Tanos R, Tellew J, Boitano AE, Bisson WH, Kolluri SK, Cooke MP, Perdew GH. Identification of a High-Affinity Ligand That Exhibits Complete Aryl Hydrocarbon Receptor Antagonism. J Pharmacol Exp Ther 2011;338:318-27.

77. Murray IA, Krishnegowda G, DiNatale BC, Flaveny C, Chiaro C, Lin J-M, Sharma AK, Amin S, Perdew GH. Development of a Selective Modulator of Aryl Hydrocarbon (Ah) Receptor Activity that Exhibits Anti-Inflammatory Properties. Chem Res Toxicol 2010;23:955-66. 